\title{
PEMANFAATAN ONGGOK SEBAGAI PAKAN ALTERNATIF USAHA PETERNAKAN DAN PERIKANAN DI DESA TAMBAH DADI, KECAMATAN PURBOLINGGO, LAMPUNG TIMUR
}

\author{
Mahfut $^{1}$, Tundjung Tripeni Handayani ${ }^{2}$, Sri Wahyuningsih ${ }^{3}$, Eti Ernawiati ${ }^{4}$ \\ 1,2,3,4 Jurusan Biologi, Fakultas Matematika dan Ilmu Pengetahuan Alam, Universitas Lampung, Lampung
}

emailmahfut.mipa@fmipa.unila.ac.id

\begin{abstract}
ABSTRAK
Tambah Dadi adalah sebuah desa yang terletak di Kecamatan Purbolinggo, Lampung Timur dengan salah satu keunggulan pertanian tanaman ubi kayu. Dalam proses pengolahannya, keberadaan limbah onggok yang menumpuk dan menjadi masalah lingkungan belum dimanfaatkan dengan baik oleh warga setempat. Limbah tanaman ini sebenarnya sangat potensial sebagai pakan ternak alternatif dalam usaha peternakan dan pertanian, karena tersedia dalam jumlah yang besar dan murah. Keuntungan lain pemanfaatan onggok yaitu dapat mengurangi dampak pencemaran lingkungan dan menghemat devisa. Meskipun limbah, onggok memiliki kandungan serat yang tinggi sehingga masih mencukupi kebutuhan gizi sebagai pakan alternatif. Berdasarkan hal tersebut, kegiatan Pengabdian kepada Masyarakat Pemanfaatan Onggok Sebagai Pakan Alternatif Usaha Peternakan dan Perikanan di Desa Tambah Dadi, Kecamatan Purbolinggo, Lampung Timur ini perlu dilakukan untuk memberikan pengetahuan kepada masyarakat sehingga masyarakat dapat menghemat biaya produksi dan memperoleh tambahan penghasilan.
\end{abstract}

Kata Kunci: onggok, limbah singkong, pakan teknak, pakan alternatif, tambah dadi.

\begin{abstract}
Tambah Dadi is a village located in the district of Purbolinggo, East Lampung with one of the advantages of cassava farming. In the treatment process, the existence of onggok waste which has accumulated and become an environmental problem has not been well utilized by local residents. This crop waste is actually very potential as an alternative animal feed in the livestock and agriculture business, because it is available in large quantities and cheap. Another advantage of using onggok is that it can reduce the impact of environmental pollution and save foreign exchange. Even though it is waste, onggok has a high fiber content so that it still meets the nutritional needs as an alternative feed. Based on this, community service activities Utilization of Cassava as an Alternative Feed for Livestock and Fisheries Business in the Village of Dadi, Purbolinggo District, East Lampung needs to be done to provide knowledge to the community so that the community can save on production costs and obtain additional income.
\end{abstract}

Keyword: onggok, cassava waste, animal feed, alternative feed, Tambah Dadi. 


\section{PENDAHULUAN}

Tanaman ubi kayu (Manihot utilissima) adalah komoditas tanaman pangan yang cukup potensial di Indonesia, termasuk di Desa Tambah Dadi, Kecamatan Purbolinggo, Lampung Timur. Tanaman ini termasuk dalam famili Euphorbiaceae dapat tumbuh dengan mudah hampir di semua jenis tanah dan tahan terhadap serangan hama maupun penyakit (Kiramang; 2011; Ali, 2018; Purwanti, 2012). Pada umumnya, umbi ubi kayu dimanfaatkan sebagai bahan pangan sumber karbohidrat $(54,2 \%)$, industri tepung tapioka $(19,70 \%)$, industri pakan ternak $(1,80 \%)$, industri non pangan lainnya (8,50\%) dan sekitar 15,80\% diekspor (Vidyana dkk., 2017).

Produksi ubi kayu di Lampung Timur, termasuk di Desa Tambah Dadi, mengalami peningkatan yang cukup pesat dalam lima tahun terakhir yaitu 7,4 - 9,2 juta ton per tahun (Erwanto, 2020). Peningkatan produksi tersebut menyebabkan limbah pengolahan ubi kayu dan agroindustrinya juga meningkat sehingga menimbulkan permasalahan baru (Muktiani, 2002). Padahal sebenarnya limbah tersebut cukup potensial digunakan sebagai pakan alternatif dalam usaha budidaya ikan, unggas, dan hewan ruminansia. Bahan pakan yang berasal dari limbah pascapanen tanaman ubi kayu antara lain pucuk ubi kayu, batang ubi kayu, kulit ubi kayu, bonggol ubi kayu, gaplek afkir, singkong afkir, dan gamblong atau onggok tergolong sebagai pakan sumber karbohidrat mudah dicerna (Suprayogi, 2010; Haryanto, 1997; Manik, 1985).

Limbah onggok hasil usaha pengolahan ubi kayu di Desa Tambah Dadi, Kecamatan Purbolinggo, Lampung Timur telah menimbulkan permasalahan lingkungan dan keberadaannya belum dimanfaatkan dengan baik oleh masyarakat setempat. Sampai saat ini pemanfaatan limbah onggok sebagai pakan alternatif dalam usaha budidaya perikanan dan peternakan masih sedikit dan belum maksimal, meskipun kondisi lapangan sangat cocok untuk budidaya ini. Kegiatan Pengabdian kepada Masyarakat "Pemanfaatan Onggok Sebagai Pakan Alternatif Usaha Peternakan dan Perikanan di Desa Tambah Dadi, Kecamatan Purbolinggo, Lampung Timur” ini perlu dilakukan untuk memberikan pengetahuan kepada masyarakat sehingga masyarakat dapat menghemat biaya produksi dan memperoleh tambahan penghasilan.

\section{METODE}

Kegiatan Pengabdian Kepada Masyarakat ini dilakukan selama 4 bulan, pada November 2019 Februari 2020. Dalam kegiatan ini melibatkan mahasiswa dan masyarakat setempat. Kegiatan ini 
$\overline{\text { merupakan bagian dari rangkaian acara Kemah Wisata Ilmiah (KWI) Fakultas MIPA Universitas }}$ Lampung 2019. Metode pelaksanaaan kegiatan ini melalui penyuluhan dan pelatihan dengan sasaran utama adalah masyarakat di Desa Tambah Dadi, Kecamatan Purbolinggo, Lampung Timur.

\section{PEMBAHASAN}

Kegiatan dilaksanakan pada hari Senin, tanggal 1 November 2019 di balai desa, Desa Tambah Dadi, Kecamatan Purbolinggo, Lampung Timur. Kegiatan penyuluhan ini dihadiri oleh mahasiswa dan warga. Selain pemberian materi yang meliputi manfaat onggok dan teknik pembuatan pakan alternatif, juga dilakukan diskusi secara langsung dengan mahasiswa dan warga (Gambar 1 dan 2).
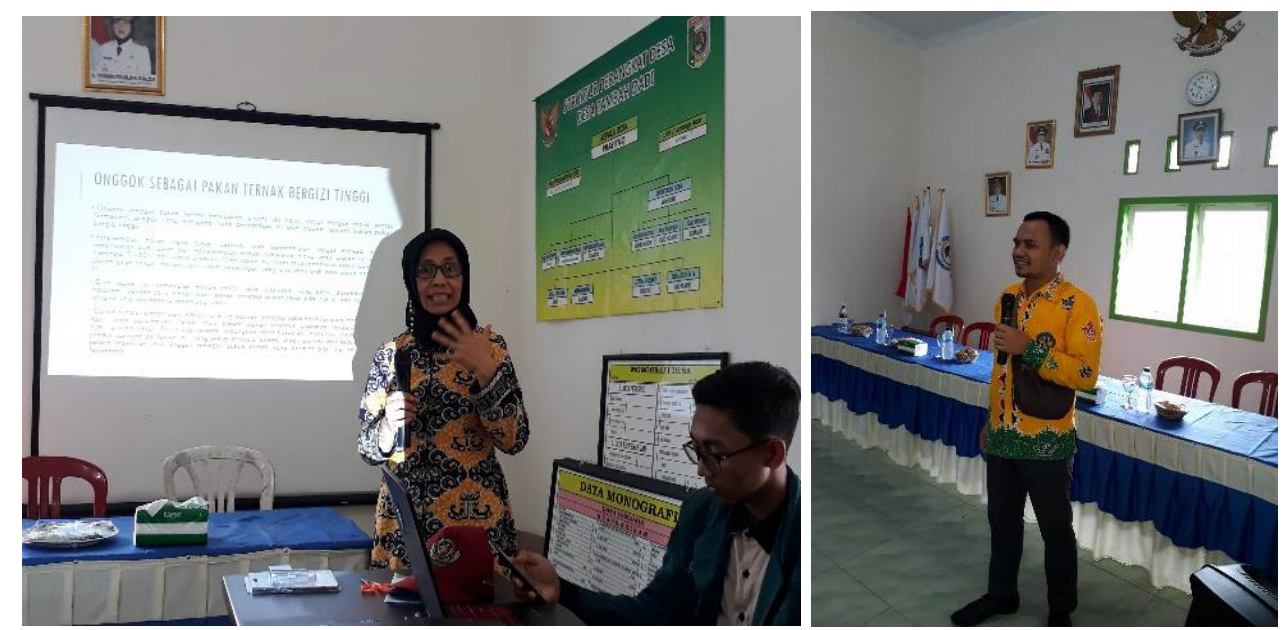

Gambar 1. Pemberian materi penyuluhan oleh Dra. Tundjung Tripeni Handayani, M.S. dan Dr. Mahfut, S.Si., M.Sc.
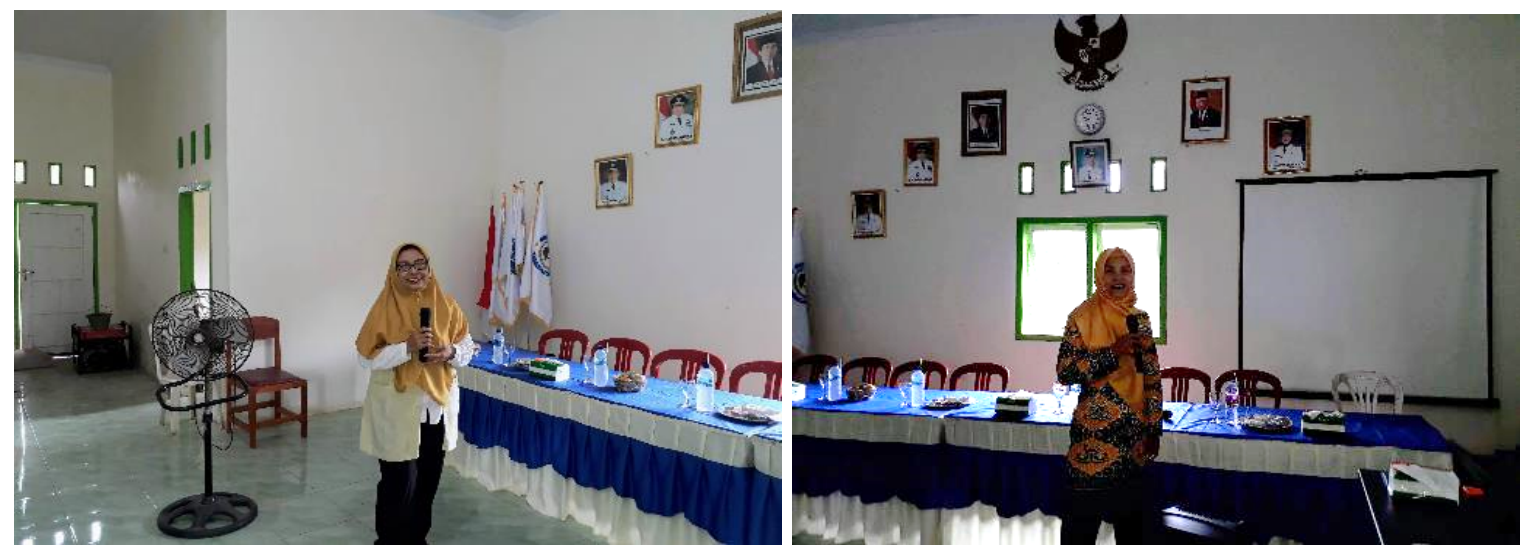

Gambar 2. Pemberian materi penyuluhan oleh Dr. Sri Wahyuningsih, M.Si., dan Dra. Eti Ernawiati, M.P. 
Acara dihadiri oleh Kepala Desa dan warga Desa Tambah Dadi, Kecamatan Purbolinggo, Lampung Timur serta mahasiswa FMIPA Universitas Lampung yang sedang mengadakan Kemah Wisata Ilmiah (KWI) 2019 (Gambar 3 dan 4).
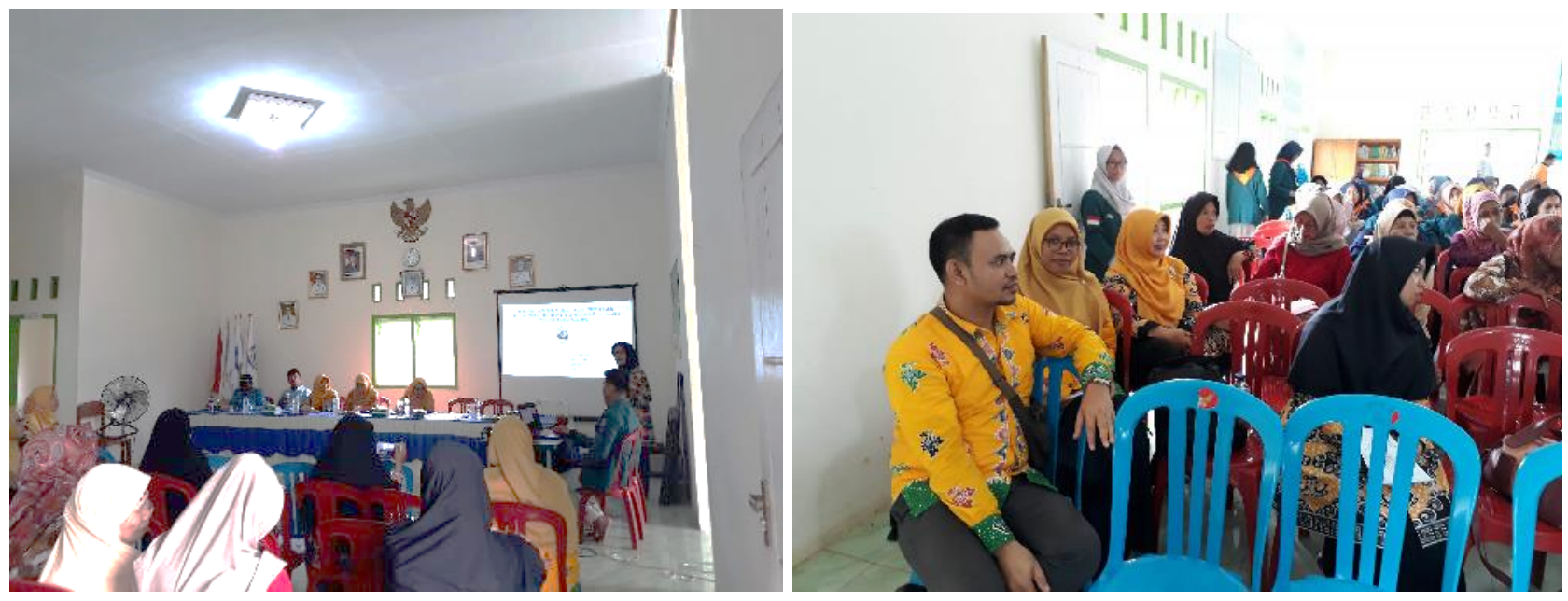

Gambar 3. Peserta kegiatan pengabdian masyarakat dari warga Desa Tambah Dadi, Kecamatan Purbolinggo, Lampung Timur.
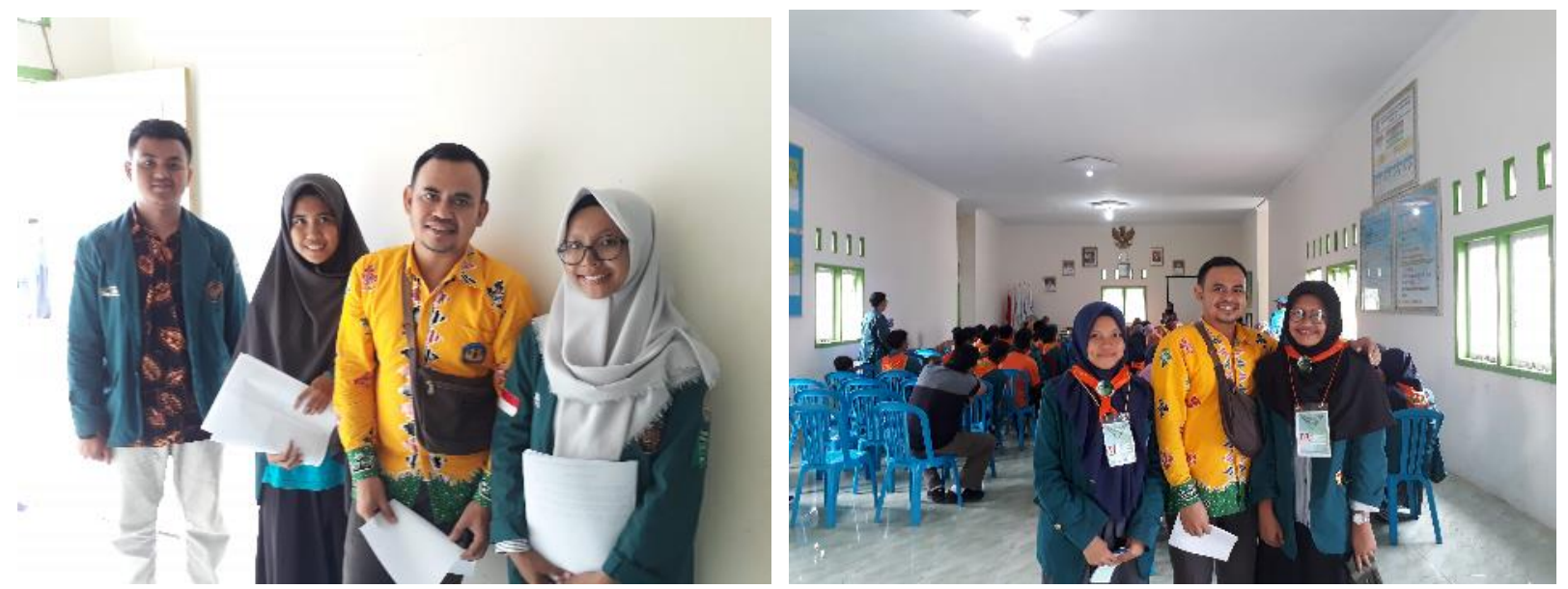

Gambar 4. Peserta kegiatan pengabdian masyarakat dari mahasiswa FMIPA Universitas Lampung Acara dilanjutkan dengan diskusi dan evaluasi pemahaman peserta kegiatan (Gambar 5). 

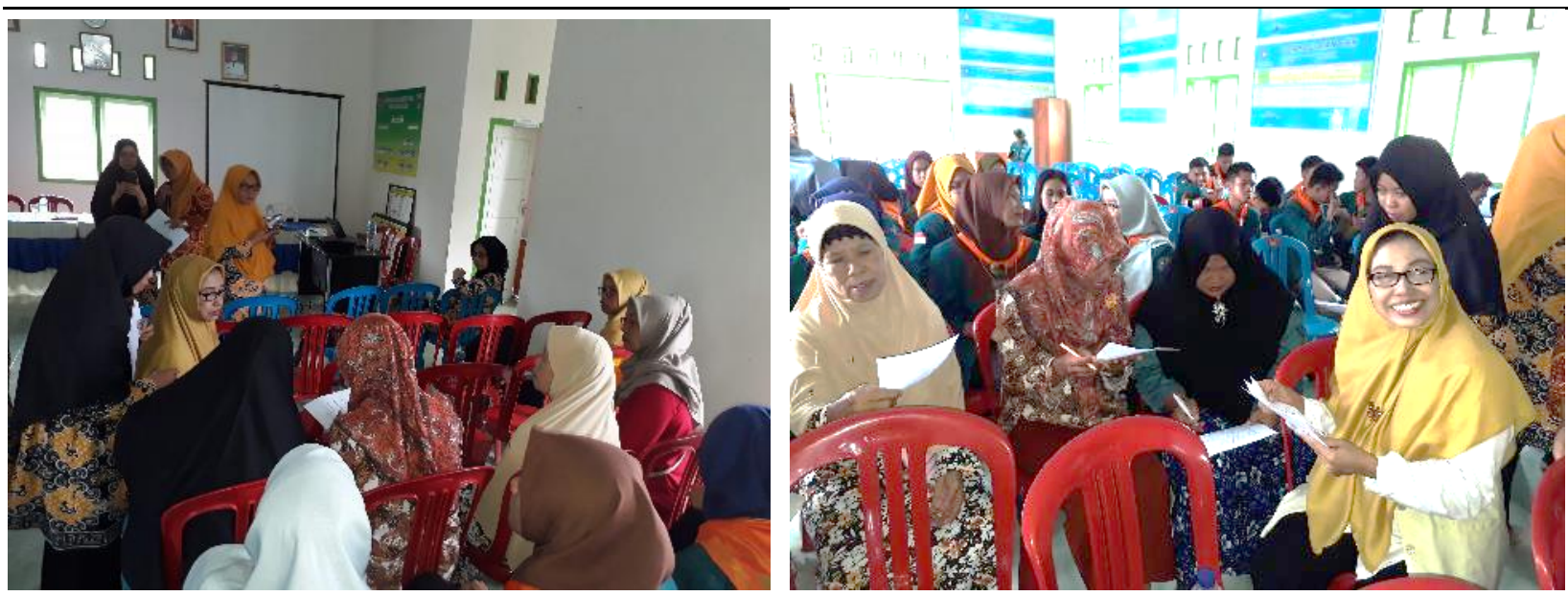

Gambar 5. Sesi diskusi dan evaluasi pemahaman peserta kegiatan

Hasil sementara mengenai pengetahuan yang diperoleh peserta diketahui melalui evaluasi terhadap peserta pelatihan. Evaluasi bertujuan untuk mendapatkan masukan yang dapat dijadikan dasar untuk kegiatan lanjutan yang akan dilaksanakan (Mahfut dan Wahyuningsih, 2019; Mahfut dan Yulianty, 2019). Secara umum peserta pelatihan banyak yang mengetahui tentang manfaaat onggok, tetapi belum mengetahui teknik pembuatan fermentasi pakan alternatif onggok. Berdasarkan data hasil evaluasi yang diketahui bahwa terjadi peningkatan pengetahuan dan pemahaman peserta kegiatan.

Secara umum peserta pelatihan banyak yang mengetahui tentang manfaat onggok. Semua peserta pelatihan (100\%) mengetahui onggok merupakan limbah padat dari usaha industri berbahan dasar singkong. Pengetahuan tentang limbah onggok ini penting diberikan kepada peserta kegiatan karena merupakan pengetahuan dasar warga dalam upaya pemenuhan pemanfaatan limbah onggok. Selain itu, data menunjukkan bahwa sampai saat ini wilayah Desa Tambah Dadi merupakan kawasan produksi singkong yang tinggi (Erwanto, 2020). Hal yang sama juga diperoleh, dimana semua peserta (100\%) menyampaikan memiliki hewan ternak. Tetapi salah satu peserta pelatihan (4,54\%) yang melaporkan pernah mendapatkan penyuluhan pembuatan pakan alternatif onggok, serta hanya 2 orang peserta saja yang mengetahuai $(9,09 \%)$ bahwa telah menggunakan onggok sebagai pakan alternatif dengan cara fermentasi. Sebagian peserta, yaitu 5 orang $(22,72 \%)$ mengetahui salah satu manfaat lain onggok selain sebagai pakan yaitu sebagai bahan dasar pembuatan obat nyamuk bakar. Peserta juga sangat sedikit $(13,63 \%)$ yang mengetahui manfaat lain limbah onggok selain sebagai pakan ternak. Data yang berbeda diketahui, dimana seluruh peserta (100\%) tidak mengetahui bahwa teknik 
pembuatan obat nyamuk dan saus berbahan limbah onggok. Seluruh peserta (100\%) mengharapkan adanya kelanjutan kegiatan pengabdian masyarakat mengenai pemanfaatan limbah onggok selain sebagai pakan alternatif.

Berdasarkan data hasil evaluasi yang diperoleh diketahui bahwa terjadi peningkatan pengetahuan dan pemahaman peserta pelatihan mengenai pemanfaatan pakan alternatif onggok. Nilai rata-rata pre-test adalah 56,36 dan setelah pemberian materi dan pelatihan pada peserta terjadi peningkatan secara signifikan yaitu hasil rata-rata post-test 78. Terjadi peningkatan sebesar 21,64 point. Persentase peningkatan nilai sebelum dan sesudah kegiatan adalah sebesar 34,72\%. Harapan kedepannya tidak hanya sebatas peningkatan pengetahuan dan pemahaman dalam peserta kegiatan, tetapi dapat diterapkan dalam kehidupan sehari-hari dan dapat menularkan pengetahuan yang diperoleh selama pelatihan kepada keluarga, kerabat dan masyarakat di Deasa Tambah Dadi, Kecamatan Purbolinggo, Lampung Timur. Selain itu diharapkan adanya upaya nyata dari warga dalam pemanfaatan pakan alternatif onggok.

\section{SIMPULAN}

Hasil yang diperoleh dalam pelatihan ini dapat disimpulkan bahwa terjadi peningkatan pengetahuan dan pemahaman peserta kegiatan dalam pemanfaatan pakan alternatif onggok, dengan rata-rata persentase peningkatan peserta pelatihan sebesar 34,72\%. Kami menyarankan agar perlu monitoring setiap semester dalam rangka menumbuhkan semangat dalam mengembangkan pemanfaatan pakan alternatif onggok.

\section{DAFTAR PUSTAKA}

Ali, U. 2018. Pengaruh Penggunaan Onggok dan Isi Rumen Sapi dalam Pakan Komplit Terhadap Penampilan Kambing Peranakan Etawah. Skripsi. Universitas Islam Malang. Hal: 1-10.

Erwanto. 2020. Ubikayu, Komoditas Harapan Petani Lampung Berjaya. https://lampung.rilis.id/Ubikayu-Komoditas-Harapan-Petani-Lampung-Berjaya. Diakses 23 November 2020.

Mahfut dan Wahyuningsih, S. 2019. Pengenalan Teknik Budidaya Kelengkeng Super Sleman Berbasis Lingkungan. Jurnal Solma. 8(2): 201-209. 
Mahfut dan Yulianty. 2019. Chili Cultivation Technique Using Fermentation of Liquid Organic Fertilizer as Catfish Waste Utilization in Tasik Madu Village, Merbau Mataram. Pelita Eksakta. 2(2): 164-171.

Kiramang, K. 2011. Potensi dan Pemanfaatan Onggok Dalam Ransum Unggas. Badan Penelitian dan Pengembangan Pertanian: Kementerian Pertanian. Jurnal Teknosains. 5(2): 155-163.

Purwanti, FW. 2012. Kualitas Nutrien Onggok yang Difermentasi Aspergillus Niger Dengan Penambahan Level Urea dan Zeolit yang Berbeda. Skripsi. Institut Pertanian Bogor. Hal: 1-63.

Suprayogi, WPS. 2010. Inkorporasi Sulfur Dalam Protein Onggok Melalui Teknologi Fermentasi Menggunakan Saccharomyces cerevisiae. Caraka Tani. 25:34-37.

Haryanto, H. 1997. Pengaruh Lama Fermentasi Dengan Menggunakan Aspergillus niger Terhadap Kadar Asam Sianida, Protein Kasar dan Serat Kasar Inti Biji Karet. Skripsi. Universitas Jambi.

Manik, I.G. 1985. Pengaruh Ubi Kayu dalam Campuran dengan Urea sebagai Ransum penguat terhadap Metabolisme Glukosa, Nitrogen dan Energi pada Kambing Menyusui dan Tidak Menyusui. Disertasi Institut Pertanian Bogor.

Muktiani, A. 2002. Penggunaan Hidrolisat Bulu Ayam dan Sorgum serta Suplemen Kromium Organik untuk Meningkatkan Produksi Susu pada Sapi Perah. Disertasi. Institut Pertanian Bogor.

Vidyana, INA., Tantalo, S., dan Liman. 2017. Survey of the Physical Properties and Nutrient Content of Cassava to Different Drying Methods in Two Districts of Lampung Province. Jurnal Ilmiah Peternakan Terpadu. 15(1): 71-75. 